\title{
Pharmacology and therapeutic potential of Euphorbia hirta (Syn: Euphorbia pilulifera)- A review
}

\author{
Prof Dr Ali Esmail Al-Snafi \\ Department of Pharmacology, College of Medicine, Thi qar University, Iraq.
}

\begin{abstract}
The phytochemical screening of Euphorbia hirta revealed that the plant contained reducing sugars, terpenoids, alkaloids, steroids, tannins, proteins, fats, oils, gums, mucilages, glycoside, saponin, coumarin, cardiac glycosides, anthroquinones, flavanoids and phenolic compounds. The previous pharmacological studies showed that Euphorbia hirta exerted antioxidant, antimicrobial, sedative anxiolytic, antiepileptic, antiinflammatory, analgesic, antipyretic, antihistaminic, antiasthmatic, antidiabetic, anticancer, wound healing, gastrointestinal, diuretic, antiparasitic, immunological, hepatoprotective, galactogenic, angiotensin converting enzyme inhibiting and anti-dipsogenic activities. The current review discussed the chemical constituents, pharmacological and therapeutic potential of Euphorbia hirta.
\end{abstract}

Keywords: chemical content, pharmacology, therapeutic potential, Euphorbia hirta

\section{INTRODUCTION:}

Herbal medicine is the oldest form of medicine known to mankind. It was the mainstay of many early civilizations and still the most widely practiced form of medicine in the world today. Plants generally produce many secondary metabolites which are bio-synthetically derived from primary metabolites and constitute an important source of many pharmaceutical drugs [1-50]. The phytochemical screening of Euphorbia hirta revealed the presence of reducing sugars, terpenoids, alkaloids, steroids, tannins, proteins, fats, oils, gums, mucilages, glycoside, saponin, coumarin, cardiac glycosides, anthroquinones, flavanoids and phenolic compounds. The previous pharmacological studies showed that Euphorbia hirta exerted antioxidant, antimicrobial, sedative anxiolytic, antiepileptic, antiinflammatory, analgesic, antipyretic, antihistaminic, antiasthmatic, antidiabetic, anticancer, wound healing, gastrointestinal, diuretic, antiparasitic, immunological, hepatoprotective, galactogenic, angiotensin converting enzyme inhibiting and anti-dipsogenic activities. The current review will highlight the chemical constituents, pharmacological and therapeutic potential of Euphorbia hirta.

\section{Synonyms:}

Chamaesyce gemella (Lag.) Small, Chamaesyce hirta (L.) Millsp., Chamaesyce hirta (L.) Small, Chamaesyce hirta var. glaberrima (Koidz.) H. Hara, Chamaesyce hirta f. glaberrima (Koidz.) Hurus., Chamaesyce hirta var. laeticincta Croizat, Chamaesyce hirta f. litoralis Hurus., Chamaesyce karwinskyi (Boiss.) Millsp., Chamaesyce pekinensis var. glaberrima (Koidz.) Makino \& Nemoto, Chamaesyce pilulifera var. glaberrima (Koidz.) H. Hara, Chamaesyce rosei Millsp., Desmonema hirta (L.) Raf., Ditritea hirta (L.) Raf., Euphorbia bancana Miq., Euphorbia capitata Lam., Euphorbia chrysochaeta W. Fitzg., Euphorbia gemella Lag., Euphorbia globulifera Kunth, Euphorbia hirta var. destituta L. C. Wheeler, Euphorbia hirta var. glaberrima Koidz., Euphorbia karwinskyi Boiss., Euphorbia nodiflora Steud., Euphorbia obliterata Jacq., Euphorbia pilulifera Jacq., Euphorbia pilulifera var. arechavaletae Herter, Euphorbia pilulifera var. discolor Engelm., Euphorbia pilulifera var. glabrescens Thell., Euphorbia pilulifera var. guaranitica Chodat \& Hassl., Euphorbia pilulifera var. hirta (L.) Thell., Euphorbia pilulifera var. hirta (L.) Griseb., Euphorbia pilulifera f. humifusa Domin, Euphorbia pilulifera var. obliterata (Jacq.) Hitchc., Euphorbia pilulifera f. rubromaculata Domin, Euphorbia pilulifera f. viridis Domin and Tithymalus pilulifer (L.) Moench [51].

Taxonomic classification:

Kingdom: Plantae, Subkingdom: Viridaeplantae, Infrakingdom: Straptophyta, Division: Tracheophyta, Subdivision: Spermatophytina, Infradivision: Angiosperms, Class: Magnoliopsida, Superorder: Rosanae, Order: Malpighiales, Family: Euphorbiaceae,Genus: Euphorbia, Species: Euphorbia hirta (Euphorbia pilulifera)[52]. 


\section{Common names:}

Arabic: labeinah, Em elhaleeb, Euphorbia; English: asthma plant, Asthuma weed, garden spurge, pill-bearing spurge, snakeweed; Hindi: Dudhi; Indonesia: Daun Biji Kcang, Philippines: Botobotonis; Spanish: golondrina, hierba de boca, lecherón chico, lecherita, pichoga, yerba de sapo; Thailand: Nam Nom Raatchasee [52-53].

\section{Distribution:}

The plant is distributed in Northern America: (United States, Mexico); Southern America: (Brazil, Antigua and Barbuda, Barbados, Dominica, Grenada, Guadeloupe, Martinique, Montserrat, St. Kitts and Nevis, St. Lucia, St. Vincent and Grenadines, Trinidad and Tobago, Belize, Costa Rica, El Salvador, Guatemala, Honduras, Nicaragua, Panama, French Guiana, Guyana, Suriname, Venezuela, Argentina, Chile, Paraguay, Bolivia, Colombia, Ecuador, Peru); Africa: (Tanzania, Uganda, Cape Verde, Chad, Djibouti, Eritrea, Ethiopia, Somalia, Angola, Malawi, Mozambique, Zambia, Zimbabwe, Botswana, South Africa, Liberia, Egypt, Mali, Niger, Nigeria, Senegal, Sierra Leone, Togo, Cameroon, Central African Republic, Equatorial Guinea, Gabon, Rwanda, Zaire, Madagascar, Mauritius, Reunion, Seychelles); Asia: (Oman, Yemen, Taiwan, Palestine, Lebanon, Syria, Bhutan, India, Nepal, Pakistan, Sri Lanka, Myanmar, Thailand, Indonesia, Malaysia, Papua New Guinea, Philippines) and Australasia: (Australasia, New Zealand) [53].

\section{Description:}

A small, erect or ascending annual herb reaching up to $50 \mathrm{~cm}$, with hairy stems. The leaves are opposite, elliptical, oblong or oblong-lanceolate, with a faintly toothed margin and darker on the upper surface. The flowers are small, numerous and crowded together in dense cymes about $1 \mathrm{~cm}$ in diameter. The fruits are yellow, three-celled, hairy, keeled capsules, 1-2 mm in diameter, containing three brown four-sided angular wrinkled seeds [54].

\section{Traditional uses:}

Euphorbia hirta was used in the treatment of gastrointestinal disorders, bronchial and other respiratory diseases, conjunctivitis, to increase milk flow in lactating women and for other female diseases [55-56].It was also used for intestinal parasites, diarrhoea, peptic ulcers, heartburn, vomiting, amoebic dysentery, asthma, bronchitis, hay fever, laryngeal spasms, emphysema, coughs, colds, kidney stones, menstrual problems, sterility, venereal diseases, skin and mucous membranes diseases, including (warts, scabies, tinea, thrush, aphthae, fungal afflictions, measles), as an antiseptic to treat wounds, sores, and conjunctivitis. The plant has a reputation as an analgesic to treat severe headache, toothache, rheumatism, colic, and pains during pregnancy. It was also used as an antidote and pain relief of scorpion stings and snakebites [57]. In India it was used to treat worm infections in children and for dysentery, gonorrhea, jaundice, pimples, digestive problems and tumors. The fresh milky latex was applied to wounds and warts. Roots of the plant were used in sprains and inflammation, miscarriage, epilepsy, maggots in wounds and irregular growth of teeth [58].

Medicinal parts used: leaves, stem and flowers [55-58].

\section{Physiochemical characteristics:}

Total ash: 8.90, acid insoluble ash 7.84, water soluble ash 1.06, water soluble extract 7.0, ethanol soluble extract 14.85, methanol soluble extract 9.71 and moisture content $9.84(\% \mathrm{w} / \mathrm{w})$. However, moisture content of leaves 13.50 and stems 10.30 (\% W/W), ash content of leaves 18.66 and stems 21.50 (\% W/W), acid-insoluble ash of the leaves 3.50 and stems $2.50(\% \mathrm{~W} / \mathrm{W})$, protein of the leaves 9.5 and stems $3.0(\%$ $\mathrm{W} / \mathrm{W})$, fat of the leaves 25.0 and stems $14.0(\% \mathrm{~W} / \mathrm{W})$ and carbohydrate of the leaves 1.5 and stems $8.0(\%$ $\mathrm{W} / \mathrm{W})[59-60]$.

\section{II-CHEMICAL CONSTITUENTS:}

Phytochemical screening of Euphorbia hirta leaf extract revealed the presence of reducing sugars, terpenoids, alkaloids, steroids, tannins, proteins, fats, oils, gums, mucilages, glycoside, saponin, coumarin, cardiac glycosides, anthroquinones, flavanoids and phenolic compounds. Afzelin, quercitrin and myricitrin, rutin, quercitin, euphorbin-A, euphorbin-B, euphorbin-C, euphorbin-D, 2,4,6-tri-O-galloyl- $\beta$-d-glucose, 1,3,4,6tetra-O-galloyl- $\beta$-d-glucose, kaempferol, gallic acid, and protocatechuic acid were isolated from the aerial parts of Euphorbia hirta [59-64].Six compounds have been isolated from the leaves of Euphorbia hirta and identified as gallic acid, quercitrin, myricitriu, 3,4-di-O-galloylquinic acid, 2,4,6-tri-O-galloyl-D-glucose and 1,2,3,4, 6-penta-O-galloyl-beta-D-glucose [65].Euphorbins A-E, euphorbianin, leucocyanidol, camphol and triterpenes: $\alpha$-amyrin, 24-methylencycloartenol and $\beta$-sitosterol were isolated from Euphorbia hirta [66-67]. Seven phenolic compounds [(-)-epigallocatechin gallate $16.25-29.52 \mathrm{mg} / 100 \mathrm{~g} \mathrm{dw},(-)$-epicatechin gallate 16.72-41.87 mg/100 g dw, luteolin-7-O-glucoside 5.24- $98.83 \mathrm{mg} / 100 \mathrm{~g} \mathrm{dw}$, isoquercitrin 12.30-51.87 mg/100 
$\mathrm{g} \mathrm{dw}$, syringic 51.14-68.00 mg/100 g dw, chlorogenic 48.68-79.67 mg/100 g dw and caffeic acids 0.66-1.22 $\mathrm{mg} / 100 \mathrm{~g} \mathrm{dw}$ ], and six sterols [ $\beta$-sitosterol-D-glucoside $19.08-45.76 \mathrm{mg} / 100 \mathrm{~g} \mathrm{dw}, \beta$-sitosterol 1.20-3.56 $\mathrm{mg} / 100 \mathrm{~g} \mathrm{dw}$, cholesterol $0.41-3.36 \mathrm{mg} / 100 \mathrm{~g} \mathrm{dw}$, brassicasterol $10.09-32.57 \mathrm{mg} / 100 \mathrm{~g} \mathrm{dw}$, campesterol undetected $-0.51 \mathrm{mg} / 100 \mathrm{~g} \mathrm{dw}$, stigmasterol $11.69-19.66 \mathrm{mg} / 100 \mathrm{~g} \mathrm{dw}$ ] were isolated from Euphorbia hirta [68].The total phenolic and flavonoids content of different parts (leaves, stems, flowers and roots) of Euphorbia hirta were determined. Leaves extract had the highest total phenolic content $[(206.17 \pm 1.95) \mathrm{mg}$ $\mathrm{GAE} / \mathrm{g}$ ], followed by flowers, roots and stems extracts which contained (117.08 \pm 3.10$) \mathrm{mg} \mathrm{GAE} / \mathrm{g}$, $(83.15 \pm 1.19) \mathrm{mg} \mathrm{GAE} / \mathrm{g}$, and $(65.70 \pm 1.72) \mathrm{mg} \mathrm{GAE} / \mathrm{g}$, respectively. The leaves also had the highest total flavonoids content value $[(37.970 \pm 0.003) \mathrm{mg} \mathrm{CEQ} / \mathrm{g}]$, followed by flowers, roots and stems extracts which

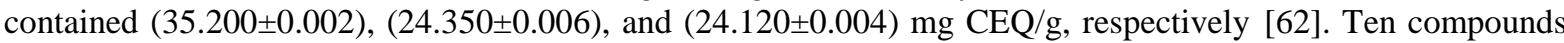
were identified from the methanolic leaf extract of Euphorbia hirta including methyl 14-methylpentadecanoate, palmitic acid, 5-methyl-1,3-oxazolidin-2-one; 2-amino-3-sulfanylpropanoic acid, S-methyl-L-cysteine, chloromorpholin-4-ium, 2,3,5-trimethyl-1 $H$-pyrrole; niacin or nicotinic acid, 4-amino-4-oxobut-2-enoic acid and 17-carboxyheptadec-9-en-1- ylium [69].Triterpenoids: $\alpha$-amyrin, $\beta$-amyrin, taraxerone, taxerol, $\beta$-amyrin acetate, taraxerone, $11 \alpha, 12 \alpha$-oxidotaraxerol, and tannins were identified in Euphorbia hirta [70]. The mineral contents of dried leaves sample were Ca: $1.1 \%$, P: $0.3 \%$, Fe: $0.03 \%$, Mg: $0.5 \%$, Mn: 0.01\%, Zn: $0.01 \%$ and $\mathrm{Cu}: 0.002 \%[71]$.

\section{Antimicrobial effects:}

\section{III-PHARMACOLOGICAL EFFECTS:}

The antimicrobial analysis of the leaf extract of Euphorbia hirta inhibited the growth of $P$. aeruginosa, S. aureus, C. albicans and T. mentagrophytes with activity index of $0.2,0.3,0.4$ and 0.2 respectively [72]. The antibacterial effect of methanol, ethyl acetate, acetone and hot water extracts (0.02$1.66 \mathrm{mg} / \mathrm{ml}$ ) of Euphorbia hirta was evaluated against multidrug- resistant (MDR) patogenes. All leaves extracts were active against the tested microorganisms, but, the best antibacterial effects were exerted by methanolic extract of the leaves against P.aeruginosa, S.aureus and E.coli (diameter of inhibition 22, 23 and 25 $\mathrm{mm})$ respectively [73].

The ethanol extract of the leaves of Euphorbia hirta was studied for its antimicrobial activity by agar well diffusion method against: Staphylococcus aureus (MTCC 2940), Bacillus ceresus, Salmonella typhi (MTCC 733), Klebsiella pneumoniae (MTCC139), Pseudomonas aeuroginosa (MTCC 741), Aspergillus niger (MTCC 277), Aspergillus fumigatus (MTCC 343), Aspergillus flavus (MTCC 418) and Rhizopus oryzae (MTCC 262). The ethanol extract of the leaves of Euphorbia hirta showed significant antimicrobial effects [74]. The agar well diffusion method was used to determine the antimicrobial activity of Euphorbia hirta against Escherichia coli, Klebsiella pneumoniae. Shigella dysentriae, Salmonella typhi and Proteus mirabilis, a group of Gram negative bacteria that frequently cause enteric infections in humans. The minimum inhibitory concentration and minimum bactericidal concentration values ranged from 25 to $100 \mathrm{mg} / \mathrm{ml}$. The growth of all the bacteria were inhibited to varying degrees [61]. The antibacterial and antifungal activity of aqueous and organic solvent (acetone, chloroform, benzene, butanol, ethanol, dimethylformamide and diethyl ether) leaf extracts of Euphorbia hirta were studied against bacterial species (Pseudomonas putida, Pseudomonas aeruginosa, Klebsiella pneumoniae, Aeromonas liquefaciens and lcaligenes spp.) and fungal species (Aspergillus niger, Aspergillus flavus, Aspergillus fumigatus, Aspergillus erythrocephalus and Fusarium spp.). All extracts showed antibacterial activity against the tested bacteria except water and butanol extracts showed no activity against Klebsiella pneumonia and Aeromonas liquefaciens. However ethanol extracts showed the highest activity $(14,12,12,14 \mathrm{~mm})$ against Pseudomonas putida, Pseudomonas aeruginosa, Klebsiella pneumoniae, Aeromonas liquefaciens respectively. On the other hand, dimethyl formamide extract showed the highest activity against Aspergillus niger $(10 \mathrm{~mm})$, butanol extract showed the highest activity against Aspergillus flavus $(12 \mathrm{~mm})$, ethanol extract showed the highest activity against Aspergillus fumigates $(13 \mathrm{~mm})$ and benzene extract showed the highest activity against Aspergillus erythrocephalus (16mm) [75].The antimicrobial activities of the methanolic extracts of Euphorbia hirta leaves, flowers, stems and roots were evaluated against four Gram positive (Staphylococcus aureus, Micrococcus sp., Bacillus subtilis and Bacillus thuringensis), four Gram negative (Escherichia coli, Klebsiella pneumonia, Salmonella typhi and P. mirabilis) and one yeast (Candida albicans). Leaves extract inhibited the growth of all tested microorganisms with larger zones of inhibition (18$28 \mathrm{~mm})$, followed by that of flowers $(9-28 \mathrm{~mm})$, which also inhibited all the bacteria except $C$. albicans. The most susceptible microbes to all extracts were S. aureus and Micrococcus sp. Root extract displayed larger inhibition zones against Gram positive bacteria than Gram negative bacteria and had larger inhibition zones compared to stem extract. The lowest MIC values were obtained against E. coli and C. albicans $(3.12 \mathrm{mg} / \mathrm{ml})$, followed by S. aureus $(12.50 \mathrm{mg} / \mathrm{ml})$ and P. mirabilis $(50.00 \mathrm{mg} / \mathrm{ml})$. All the other bacteria had MIC values of $100.00 \mathrm{mg} / \mathrm{ml}$. Scanning electron microscopic studies revealed that the cells exposed to leaf extract displayed a rough surface with multiple blends and invaginations which increased with increasing time of treatment. Cells 
exposed to leaf extract for $36 \mathrm{~h}$ showed sever damage, with abundant surface cracks which may be related to final cell collapse and loss of function [76].

The Euphorbia hirta methanol extract showed a potent antimicrobial (MIC $0.250 \mathrm{mg} / \mathrm{ml}$ against Escherichia coli and Klebsiella pneumonia [77].The antibacterial activity of the ethanol and petroleum ether extracts of Euphorbia hirta was investigated against Staphylococcus aureus, Salmonella typhi, Pseudomonas aureginosa, Vibrio cholera and Escherichia col. Different concentrations of crude drugs $(25 \mu \mathrm{g} / \mathrm{ml}, 50 \mu \mathrm{g} / \mathrm{ml}, 75 \mu \mathrm{g} / \mathrm{ml}$, and $100 \mu \mathrm{g} / \mathrm{ml}$ ) were tested. The result showed that ethanol and petroleum ether extracts of leaf, stem, root and bud were active against the tested bacteria. However, ethanol extracts of Euphorbia hirta have potentially deleterious effects on microorganisms [78].The antibacterial effects of Euphorbia hirta leaves extracts (methanol, n-hexane and ethyl acetate) were studied against Bacillus subtilis, Staphylococcus aureus, Escherichia coli, Vibrio cholerae, and Enterococcus faecalis at $100 \mu \mathrm{g} / \mathrm{ml}$ concentration. Among the three solvent extracts, methanol extract of Euphorbia hirta showed 10-15 mm inhibition against B. subtilis, E. coli, and $V$. cholerae whereas no activity was observed against $S$. aureus and E. faecalis at $100 \mu \mathrm{g} / \mathrm{ml}$. The ethyl acetate extract showed activity only against. B.subtilis $(12 \mathrm{~mm})$ and E. faecalis $(10 \mathrm{~mm})$, while n- hexane extract showed no activity. Antimycobacterial activity of different solvent extracts of Euphorbia hirta was also tested against $M$. tuberculosis $\mathrm{H} 37 \mathrm{Rv}$ at 250 and $500 \mu \mathrm{g} / \mathrm{ml}$ concentrations by adopting relative light unit (LRP) assay. The ethyl acetate extracts at concentration of $500 \mu \mathrm{g} / \mathrm{ml}$ showed maximum reduction in RLU (about $64.73 \%$ ) compared to methanol and n-hexane extracts [79].The antimicrobial activity of supercritical fluid crude extracts of the leaves of Euphorbia hirta was studied against four bacteria: Staphylococcus aureus, Bacillus subtilis, Escherichia coli, Pseudomonas aeruginosa, and two fungi: Aspergillus niger and Candida albicans. Euphorbia hirta extract showed antibacterial and antifungal activities, the diameters of zone of growth inhibition were B. subtilis 9.58, S. aureus 9.67, E. coli 9.17, P. aeruginosa 9.00, A. niger 7.75 and C. albicans $9.25 \mathrm{~mm}$ [80].The ethyl acetate extract of the inflorescence of Euphorbia hirta was tested for antifungal activity against Aspergillus flavus, it exhibited antifungal effects mediated by damaging of the cell membrane which could result in leakage of cellular proteins [81]. Euphorbia hirta extracts (hexane, dichloromethane, ethyl acetate and methanol), were investigated for its potential antibacterial activity towards Gram negative bacteria, Ralstonia solanacearum and Xanthomonas axonopodis pv vesicatoria. $R$. solanacearum and $X$. axonopodis were known to cause bacterial wilt and bacterial spot disease in tomato crop (Solanum lycopersicum). Among the four extracts, Euphorbia hirta methanol extract at $1280 \mathrm{mg} / \mathrm{l}$ concentration showed $90 \%$ inhibition $\left(\mathrm{IC}_{90}\right)$ of $R$. solanacearum and $X$. axonopodis growth. Euphorbia hirta methanol extract at 40 $\mathrm{mg} / \mathrm{l}$ and $640 \mathrm{mg} / \mathrm{l}$ showed $50 \%$ inhibition $\left(\mathrm{IC}_{50}\right.$ ) of $R$. solanacearum and $X$. axonopodis growth respectively [82].The antiretroviral activities of extracts of Euphorbia hirta were investigated in vitro on the MT4 human T lymphocyte cell line. The cytotoxicities of the extracts were tested by MTT cell proliferation assay, and then the direct effects of the aqueous extract on HIV-1, HIV-2 and SIV(mac251) reverse transcriptase activity were also determined. A dose-dependent inhibition of reverse transcriptase activity was observed for all three viruses. The $50 \%$ methanolic extract was found to exert a higher antiretroviral effect than that of the aqueous extract. The $50 \%$ methanolic extract was subjected to liquid-liquid partition with dichloromethane, ethyl acetate and water. Only the remaining aqueous phase exhibited significant antiviral activity and after removal of the tannins from the aqueous extract, the viral replication inhibitory effect was markedly decreased, therefore the authors concluded that tannins were most probably responsible for the high antiretroviral activity [83].The effect of herbal water of Euphorbia hirta on flu like sympoms and blood biochemical parameters especially thrombocytopenia was studied in patients with Dengue fever. Blood samples were collected on the day of enrollment and subsequently after Euphorbia hirta therapy. Before the treatment, platelet count in male patients was $<25000$, and in females $>50000$. Hematocrit values) were $>40 \%$ in males and less than $30-40 \%$ in females. Total leukocyte count (TLC) was observed in a range of $4000-11000 / \mathrm{mm}^{3}$ in both male and female subjects. IgM haemagglutination antibody titer values greater than 1:160 were observed in $71 \%$ females and $50 \%$ males. AST level was found to be $>40 \mathrm{IU} / \mathrm{L}$ in $38 \%$ female and $36 \%$ males while ALT level was $>40 \mathrm{IU} / \mathrm{L}$ in $9 \%$ females and $12 \%$ males. Platelet count and TLC were increased non significantly after treatment, while HCT value was non significantly decreased after herbal use. Over 70\% patients had slight recovery of platelet count and increased retrieval of leukopenia after herbal therapy along with recovery from fever and flu like symptoms [84].

\section{Antioxidant effect:}

The antioxidant activities of different parts (leaves, stems, flowers and roots) of Euphorbia hirta were studied by diphenyl-1-picrylhydrazyl (DPPH) assay and reducing power by cyanoferrate method. The leaves extract exhibited a maximum DPPH scavenging activity of $(72.96 \pm 0.78) \%$ followed by the flowers, roots and stems whose scavenging activities were $(52.45 \pm 0.66) \%,(48.59 \pm 0.97) \%$, and $(44.42 \pm 0.94) \%$, respectively. The $\mathrm{IC}_{50}$ for leaves, flowers, roots, stems and BHT were $0.803,0.972,0.989,1.358$ and $0.794 \mathrm{mg} / \mathrm{ml}$, respectively. The reducing power of the leaves extract was comparable with that of ascorbic acid and found to be dose 
dependent [62].The leaves extract of Euphorbia hirta was investigated for antioxidant activity. The methanolic extract of Euphorbia hirta showed DPPH scavenging activity of $89.75 \pm 0.032 \%$ and hydroxyl radical scavenging activity of $83.5 \pm 0.046 \%$ at $100 \mu \mathrm{g} / \mathrm{ml}$, while ethyl acetate fraction showed DPPH scavenging activity of $91.88 \pm 0.060 \%$ and hydroxyl radical scavenging activity of $85.53 \pm 0.023 \%$. Ethyl acetate fraction was further used for in vivo antioxidant activity. Ethyl acetate fraction showed significant in-vivo antioxidant activity, $1.207 \pm 0.10,45.85 \pm 5.2,0706 \pm 0.03$ and $0.0106 \pm 0.005$ for glutathione, superoxide dismutase, catalase activity and lipid peroxidation respectively [85]. Euphorbia hirta methanol extract $(850.23 \mu \mathrm{g} / \mathrm{ml})$ showed antioxidant activities (IC ${ }_{50}=10.57 \mu \mathrm{g} / \mathrm{ml}, 2,2$-diphenyl-1-picrylhydrazyl and superoxide-anion radical scavenging activity. The methanol extract was found to contain $23.63 \mathrm{mg}$ gallic acid equivalent per gram of the extract) [77].

\section{Central nervous effects:}

Euphorbia hirta caused sedative effects when used in high doses $(100 \mathrm{mg}$ of dried plant/kg, and more), manifested by a decrease of behavioral parameters measured by non-familiar environment tests (activitest and staircase test), whereas anticonflict effects appeared at lower doses (12.5 and $25 \mathrm{mg}$ of dried plant $/ \mathrm{kg}$ ), by an enhancement of behavioral parameters measured in the staircase test and in the light/dark choice situation test [86]. Aqueous extract of the whole plant was tested for sedative and anxiolytic effects in mice. Sedative properties could be confirmed with high doses (100 mg of dried plant/kg, and more), by a decrease of behavioral parameters measured in non-familiar environment tests. The extract also potentiated the pentobarbital sleeping effect. anticonflict effects appeared at lower doses (12.5 and $25 \mathrm{mg}$ of dried plant $/ \mathrm{kg}$ ), by an enhancement of behavioral parameters measured in the staircase test and in the light/dark choice situation test [87]. The neuropharmacological activity of whole plant extract and the active constituents were studied in rodent models of neurological disorders. The animals were treated with ethanolic extract, methanolic fraction $(150 \mathrm{mg} / \mathrm{kg} \mathrm{po})$ and isolated compound ( $\beta$-Stigmasterol glucoside). The anticonvulsant effect were evaluated against; strychnine induced convulsion, pentylenetetrazole induced seizure, and maximal electroshock induced seizure in mice. The motor co-ordination, nootropic and anxiolytic activity was assessed in rats using rota rod and cook's pole climb apparatus and elevated plus maze respectively. The methanolic fraction has shown significant anticonvulsant, locomotor, nootropic and anxiolytic activity. However the isolated compound has not shown significant neuropharmacological activity [88].

\section{Antiinflammatory, analgesic and antipyretic effects:}

Ethanol extract (95\%) from whole aerial parts of Euphorbia hirta showed antiinflammatory properties in animal models. It significantly inhibited dextran-induced rat paw edema [89].The $n$-hexane extract of the aerial parts of Euphorbia hirta and its main triterpenes (b-amyrin, 24-methylencycloartenol and b-sitosterol) contents were evaluated in 12-O-tetradecanoyl phorbol acetate (TPA) ear model in mice. Both the extract and the triterpenes exerted significant and dose-dependent anti-inflammatory activity in the TPA-induced ear model. Some dual and triplet combinations of the triterpenes were tested as anti-inflammatory agents. The results showed that the combinations were higher in magnitude as anti-inflammatory agents than those produced by each triterpene alone [66].The anti-inflammatory effect of Euphorbia hirta (ethanolic and aqueous fruits extract po) was studied in carragenan induced inflammation in rats. Ethanolic and aqueous extract possessed about 56.7 and $58.1 \%$ inhibition of the increased paw thickness respectively at $100 \mathrm{mg} / \mathrm{kg}$ bw. However, at the dose of $200 \mathrm{mg} / \mathrm{kg}$ bw, ethanolic extract caused $57.1 \%$ and aqueous extract caused $54.3 \%$ inhibition of inflammatory increase in the paw thickness when compared to solvent control [90]. The anti-inflammatory effect of Euphorbia hirta leaves methanol extract was studied on RAW246.7 macrophage pro-inflammatory cytokines production and correlated with in vivo inflammatory paw oedema model. Euphorbia hirta leaves methanol extract inhibited the cyclooxygenase mediated prostagladins E2 and nitric oxide synthsae catalyzed nitric oxide production in LPS-induced marophages. Anti-inflammatory effect of Euphorbia hirta leaves methanol extract accompanied by the reduced production of pro-inflammatory cytokines including TNF- $\alpha$, IL- 6 and IL- $1 \beta$ in a dose-dependent manner. In vivo evaluation of the effect on carrageenan-induced Wistar rat paw oedema, correlated with in vitro anti-inflammatory findings of Euphorbia hirta leaves methanol extract, as $500 \mathrm{mg} / \mathrm{kg}$ bw concentration possess anti-inflammatory effect comparable to diclofenac $(10 \mathrm{mg} / \mathrm{kg}$ bw) [91]. Lyophilised aqueous extract of Euphorbia hirta was evaluated for analgesic, antipyretic and anti-inflammatory properties in mice and rats. It exerted central analgesic properties, a dose-dependent action was obtained against chemical (writhing test) and thermic (hot plate test) stimuli, for the doses of 20 and $25 \mathrm{mg} / \mathrm{kg}$. The analgesic effect was inhibited by naloxone pretreatment, a specific morphinic antagonist compound. An antipyretic activity was obtained in yeast-induced hyperthermia at doses of 100 and $400 \mathrm{mg} / \mathrm{kg}$. Significant and dose-dependent antiinflammatory effects were observed on an acute inflammatory process (carrageenan-induced edema test in rats) at a dose of $100 \mathrm{mg} / \mathrm{kg}$ [92]. The ethanol extract of Euphorbia hirta and its active component were studied in lipopolysaccharide (LPS)-activated macrophage cells (RAW 264.7) as an established inflammation model. 
After activation, nitric oxide (NO) production and expression of iNOS protein and iNOS mRNA were measured by a colorimetric assay, western blotting, and reverse transcription polymerase chain reaction (RT-PCR). The alteration in the content of $\mathrm{PGE}_{2}$, TNFalpha, and IL-6 was also monitored. The results showed that the ethanol extract produced a remarkable anti-inflammatory effect via its active component of beta-amyrin and showed a dose-related inhibition of LPS-induced NO with inhibition of iNOS protein. However, the expression of iNOS gene was unaffected by the ethanolic extract. The extract of Euphorbia hirta and its component beta-amyrin were able to block most of the iNOS protein functions and NO induction, and could therefore be new selective NO inhibitors with great potential in treating arthritis inflammation [93].Different doses (25, 50, 100 and $200 \mathrm{mg} / \mathrm{kg}$ ) of Euphorbia hirta ethanol extract were used for treatment of adjuvant arthritis induced by subplantar injection of $0.05 \mathrm{ml}$ freshly prepared suspension $(5.0 \mathrm{mg} / \mathrm{ml})$ of steam killed mycobacterium tuberculli in liquid paraffin. Euphorbia hirta significantly reduced IL-1 $\beta$, TNF- $\alpha$, IL-2 and IFN- $\Upsilon$ in splenocytes of arthritic rats and down-regulated lipopolysaccharide (LPS)-induced nitric oxide production in peritoneal macrophages. On the other hand, 50,100, $500 \mathrm{mg} / \mathrm{kg}$ of water extract of Euphorbia hirta showed significant effects in arthritis induced by Freund's complete adjuvant containing heat- killed Mycobacterium tuberculosis. Rats treated with the intermediary and low dosages of Euphorbia hirta showed improved histology. MMP-13 levels were found to be decreased with decreasing dosages of E. hirta, while, TIMP-1 levels were found to be increase with decreasing dosages of E. hirta [94-95].

\section{Antihistaminic and antiasthmatic effects:}

Ethanol extract $(95 \%)$ from whole aerial parts of Euphorbia hirta showed antihistaminic and immunosuppressive properties in animal models. It inhibited rat peritoneal mast cell degranulation triggered by compound 48/80. It prevented eosinophil accumulation and eosinophil peroxidase activity and reduced the protein content in bronchoalveolar lavage fluid in a (mild) model of asthma. In addition, the CD4/CD8 ratio in peripheral blood was suppressed. Ethanol extract also attenuated the release of interleukin-4 (IL-4) and augmented interferon- $\gamma$ (IFN- $\gamma$ ) in ovalbumin-sensitized mouse splenocytes [89]. The anti-histaminic activity of Euphorbia hirta extract was investigated in rats, rats were sensitized by injecting subcutaneously $0.5 \mathrm{ml}$ of horse serum along with $0.5 \mathrm{ml}$ of triple antigen containing 20,000 million Bordetella pertussis bacteria. In Euphorbia hirta extract treated rats, the disruption of mast cells was $29.80 \pm 2 \%$ and intact mast cells was $71.20 \pm 2 \%$ at $50 \mathrm{mg} / \mathrm{kg}$ bw. However, $24.70 \pm 2 \%$ disrupted and $81.10 \pm 2 \%$ intact mast cells were observed at the dose of $100 \mathrm{mg} / \mathrm{kg}$ body weight which was quite similar to standard drug, prednisolone [96].To determine if the antispasmodic action of euphorbia is myotropic or neurotropic, the antispasmodic properties of the plant were studied against contractions by cholinergic and histaminic drugs, allergic reactions, and direct muscular action on smooth muscle (trachea), it possessed direct muscular action which was completely reversible. It had little, if any, relaxing properties on normal muscle [97].

\section{Antidiabetic effect:}

The ethanol extract of Euphorbia hirta showed a significant decreased blood glucose level on alloxaninduced diabetic rats [98]. The antidiabetic effect of ethanolic extract of leaf, flower and stem of Euphorbia hirta was investigated in streptozotocin induced diabetic mice. Oral administration of all extracts induced significant reduction in blood glucose level at the $15^{\text {th }}$ day of the study [99]. Ethanol extract and ethylacetate fractions showed $\alpha$-glucosidase inhibition activity. Based on the in vitro and in vivo test, Euphorbia hirta ethanolic extract and ethyl acetate anti-diabetes mechanism was related to its antioxidant capacity and to $\alpha$ glucosidase inhibitory properties [100].

\section{Anticancer effect:}

Brine shrimp lethality assay was used to study the cytotoxicity of Euphorbia hirta. The results showed that the $\mathrm{LC}_{50}$ of ethyl acetate and acetone extract of Euphorbia hirta were 71.15 and $92.15 \mathrm{ug} / \mathrm{ml}$ respectively [101].On the other hand, flavonol glycosides (afzelin, quercitrin and myricitrin) isolated from the methanolic extract of the aerial parts of Euphorbia hirta, exhibited little cytotoxic property against human epidermoid carcinoma KB 3-1 cells [102].The leaf extract of Euphorbia hirta also appeared toxic based on the viability of the cells by in vitro analysis on the lymphocytes from normal blood cells [72].

\section{Gastrointestinal effects:}

The antiulcer effect of Euphorbia hirta ( $200 \& 400 \mathrm{mg} / \mathrm{kg}$ orally), were studied in many ulcer inducing models in rats. In pyloric ligation model, Euphorbia hirta at doses of 200 and $400 \mathrm{mg} / \mathrm{kg}$ inhibited ulcer formation significantly (50.46\% and $87.43 \%$ respectively) and reduced gastric secretion. In $\mathrm{HCl} / \mathrm{Ethanol}$ induced ulcerated rats, gastric wall mucus was significantly preserved by the Euphorbia hirta pretreatment at doses of 200 and $400 \mathrm{mg} / \mathrm{kg}$. The Euphorbia hirta gastroprotective potential was attributed to preservation of gastric mucus secretion and anti secretary action [103].The lyophilized decoction of Euphorbia hirta whole 
plant showed antidiarrhoeic effects in experimental diarrhoea induced by castor oil, arachidonic acid, and prostaglandin E2. The lyophilized decoction delayed small intestinal transit accelerated by castor oil but not in normal conditions [104]. The plant also inhibited contractions induced by cholinergic and histaminic drugs, allergic reactions, and direct muscular action on smooth muscle (ileum, uterus) [97]. At a concentration of 80 $\mu \mathrm{g} / \mathrm{ml}$ in an organ bath, the extract exhibited more than $70 \%$ inhibition of acetylcholine and/or KCI -induced contractions on isolated guinea pig ileum. The growth of Entamoeba histolytica was inhibited by polyphenolic extract of the whole plant, the minimum active concentration was less than $10 \mathrm{pg} / \mathrm{ml}$ [105].

\section{Wound and burn healing effects:}

The wound healing effect of Euphorbia hirta was investigated by in vitrolin vivo wound healing models using human dermal fibroblast cell line, and in vivo in Wistar rats. Wound contraction, hydroxyproline content and the protein expression of COL3A1, bFGF, Smad-2,-3,-4 and -7 were measured. The Euphorbia hirta methanol extract showed significant fibroblast proliferating activity $(112 \%$ at $12.5 \mu \mathrm{g} / \mathrm{ml})$ as compared to other extracts. In vivo study also supported the wound healing potential of methanol extract, as evidenced by faster wound contraction, higher hydroxyproline $(4.240 \mathrm{mg} / 100 \mathrm{mg}$ tissue $)$ and improved histopathology of granulation tissue as compared to control and gentamicin sulfate-treated groups. Western blot also revealed a significantly altered expression of Smad-mediated proteins resulting in collagen production [77]. The wound healing effect of Euphorbia hirta ethanolic leaves was evaluated in excision wound model (cutting away 500 $\mathrm{mm}^{2}$ of the skin on the anterio-dorsal side under anesthesia) in rats. The extract was formulated as an ointment $(5 \%$ and $10 \% \mathrm{~W} / \mathrm{W})$. The wound contraction was observed at different time intervals. Both the concentrations of Euphorbia hirta leaf extracts showed significant $(\mathrm{P}<0.001)$ wound contraction [106].The effect of whole Euphorbia hirta ethanol extract as $2 \% \mathrm{~W} / \mathrm{W}$ cream was evaluated for burn wound healing activity in rats. The percentage reduction in original wound of Euphorbia hirta treated animals was showed significant burn wound healing activity [107].

\section{Diuretic effect:}

The diuretic effect of the Euphorbia hirta leaf extracts was evaluated in rats. The water and ethanol extracts (50 and $100 \mathrm{mg} / \mathrm{kg}$ ) of the plant produced time-dependent increase in urine output. The water extract increased the urine excretion of $\mathrm{Na}^{+}, \mathrm{K}^{+}$and $\mathrm{HCO}^{-}$. while, the ethanol extract increased the excretion of $\mathrm{HCO}^{-}$ , decreased the loss of $\mathrm{K}^{+}$and had little effect on renal removal of $\mathrm{Na}^{+}[108]$.

\section{Platelet augmentation activity:}

The platelet augmentation activity of Euphorbia was studied as a possible beneficial plant in treatment of thrombocytopenia. Platelet count reduction in rats was induced by oral administration of $0.083 \mathrm{mg} / \mathrm{kg}$ body weight of anagrelide. A solution of the lyophilized aqueous plant samples were administered for 9 days. Pre-and post-treatment blood samples for platelet counts were taken on the $10^{\text {th }}$ day. Results showed that extracts from Euphorbia hirta possessed significant platelet augmentation $(\mathrm{P}<0.05)$ activity [109].

\section{Anti-parasitic effects:}

The in vivo antimalarial activity of the Euphorbia hirta extract (200, 400 and $800 \mathrm{mg} / \mathrm{kg}$ body weight) was studied against $P$. berghei infected mice. The results showed that the extract had significant $(\mathrm{P}<0.05)$ suppressive activity of $51-59 \%$ and prophylactic activity of $25-50 \%$ when compared with chloroquine that gave 95 and $81 \%$ suppressive and prophylactic antiplasmodial activities respectively. The antiplasmodial action of the extract was not related to the oxidation of red blood cell membrane lipids as increasing extract concentration results in the reduction of the enzymatic activities of SOD and GPx, and concentrations of GSH and TBARS [110]. The growth of Entamoeba histolytica was inhibited by polyphenolic extract of the whole plant, the minimum active concentration was less than $10 \mathrm{pg} / \mathrm{ml}$ [105]. Bioassay-guided fractionation of the methanolic extracts of Euphorbia hirta aerial parts led to the isolation of flavonol glycosides afzelin, quercitrin and myricitrin. All these compounds showed proliferation inhibition of Plasmodium falciparum., with $\mathrm{IC}_{50}$ values of 1.1, 4.1, $5.4 \mu \mathrm{g} / \mathrm{ml}$, respectively [63]. The anthelmintic efficacy of the aqueous crude extract of Euphorbia hirta was studied in 20 Nigerian dogs naturally infected with nematodes. Two groups were treated with aqueous crude extracts of Euphorbia hirta using intramuscular and oral routes for 3 consecutive days and was repeated after 2 weeks. Two weeks after treatment, blood and faecal samples were collected to evaluate haematological values and faecal egg counts. Aqueous crude extracts of Euphorbia hirta produced a significant increase $(\mathrm{P}<0.05)$ in $\mathrm{PCV}, \mathrm{RBC}, \mathrm{Hb}, \mathrm{WBC}$ and lymphocyte counts. The faecal egg counts also showed a remarkable and significant reduction. The reduction in faecal egg counts was more pronounced with the extract administered through the oral route when compared with the intramuscular route. The effects of the plant extracts were broad spectrum in action [111]. The larvicidal effect of many extracts of Euphorbia hirta, was evaluated against the early fourth instar larvae of Aedes aegypti L. and Culex quinquefasciatus. The results 
revealed that $\mathrm{LC}_{50}$ of petroleum ether extract of E. hirta, was 272.36 ppm against A. aegypti and $424.94 \mathrm{ppm}$ against $C$ quinquefasciatus [112].

The aqueous stem bark and leaf extracts of Euphorbia hirta showed potent molluscicidal activity. Concentration of $40 \%$ and $80 \%$ of $\mathrm{LC}_{50}$ of aqueous stem bark and leaf extracts significantly $(\mathrm{P}<0.05)$ alter the levels of total protein, total free amino acid, nucleic acids (DNA and RNA) and the activity of enzyme protease and acid and alkaline phosphatase in various tissues of the vector snail Lymnaea acuminata in time and dose dependent manner [113].

\section{Immunological effects:}

The immunomodulatory activity of the ethanol extract of aerial parts of Euphorbia hirta was investigated using macrophage activity testing, carbon clearance test and mast cell de-granulation assay. The ethanol extract of Euphorbia hirta increased the phagocytic index at a concentration of $80 \mathrm{mg} / \mathrm{ml}$ and 160 $\mathrm{mg} / \mathrm{ml}$. However, the ethanol extract of Euphorbia hirta was found to be cytotoxic at a concentration of 1000 $\mu \mathrm{g} / \mathrm{ml}$. Maximum phagocytic activity was evident at $62.5 \mu \mathrm{g} / \mathrm{ml}$ [114]. The immunostimulatory effect of Euphorbia hirta was studied in Cyprinus carpio. The haematological, immunological and enzymatic studies were conducted on the Euphorbia hirta medicated fish infected with Aeromonas hydrophila pathogen. The results obtained from the haematological studies showed that the RBC count, WBC count and haemoglobin content were increased in the infected fish at higher concentration of leaf extract. The feeds with leaf extract of Euphorbia hirta were able to stimulate the specific immune response by increasing the titer value of antibody. It was able to stimulate the antibody production only up to the $5^{\text {th }}$ day, when fed with higher concentrations of $(25 \mathrm{~g}$ and $50 \mathrm{~g}$ ) plant leaf extract. At higher concentration, the leaf extract of Euphorbia hirta significantly eliminated the pathogen in blood and kidney. It was observed that fish have survival percentage of the fish was significantly increased at higher concentration of Euphorbia hirta, when compared with the control [115].

\section{Hepatoprotective effect:}

The antihepatotoxic effect of hydroalcoholic extract of whole Euphorbia hirta extracts was evaluated in experimental models of liver injury in rats induced by $\mathrm{CCl}_{4}$ or paracetamol. Euphorbia hirta showed hepatoprotective activities at 125 and $250 \mathrm{mg} / \mathrm{kg}$, since serum levels of alanine aminotransferase and aspartate aminotransferase in rats given the extracts $(125$ and $250 \mathrm{mg} / \mathrm{kg})$ were significantly lower $(\mathrm{P}<0.05$ and 0.01 respectively) compare to control $\mathrm{CCl}_{4}$ or paracetamol-injured rats [116].

\section{Galactogenic effect:}

The powdered plant given to female guinea pigs before puberty, increased the development of the mammary glands and induced milk secretion [117].

\section{Angiotensin converting enzyme inhibiting and anti-dipsogenic activities:}

The methanol extract obtained from the leaves and stems of Euphorbia hirta inhibited the activity of angiotensin converting enzyme by $90 \%$ at $500 \mu \mathrm{g}$, and $50 \%$ at $160 \mu \mathrm{g}$ [118].

\section{Effect on water consumption:}

The effect of the extract on thirst was examined in Wistar rats. Intraperitoneal administration of $10 \mathrm{mg} / 100 \mathrm{mg}$ bw of the extract significantly $(\mathrm{P}<0.05)$ decreased the amount of water consumed by rats, and the effect lasted for $2 \mathrm{~h}[118]$.

\section{Side effects and toxicity:}

The acute and subchronic oral toxicity of methanol extract of Euphorbia hirta was evaluated in rats. The extract at a single dose of $5000 \mathrm{mg} / \mathrm{kg}$ did not produce signs of toxicity or mortality in the animals tested during the 14-day observation period. The $\mathrm{LD}_{50}$ of this plant was estimated to be more than $5000 \mathrm{mg} / \mathrm{kg}$. In the repeated dose 90 -day oral toxicity study, the administration of $50 \mathrm{mg} / \mathrm{kg}, 250 \mathrm{mg} / \mathrm{kg}$, and $1000 \mathrm{mg} / \mathrm{kg} / \mathrm{day}$ of Euphorbia hirta extract revealed no significant difference $(P>0.05)$ in food and water consumptions, bodyweight change, haematological and biochemical parameters, relative organ weights, and gross findings compared to the control group. Macropathology and histopathology examinations of all organs did not reveal morphological alteration. Depending on analyses of signs, behaviour, and health monitoring, the authors concluded that the long-term oral administration of Euphorbia hirta extract for 90 days did not cause subchronic toxicity [57]. However, the possible hematological and biochemical effects of ethanolic extract of Euphorbia hirta was studied in rats. Rats were given $200 \mathrm{mg} / \mathrm{kg}, 400 \mathrm{mg} / \mathrm{kg}$ and $600 \mathrm{mg} / \mathrm{kg}$ of Euphorbia hirta ethanol extract for 14days. The results showed that Euphorbia hirta caused significant increase $(\mathrm{P}<0.05)$ in RBC, WBC, PLT, Hb and PCV level while there was a reduction in lymphocytes. Euphorbia hirta extract caused significant decrease $(\mathrm{P}<0.05)$ in serum lipid profile (cholesterol, triglyceride, LDL-cholesterol and 
VLDL) when compared to normal control Wistar albino rats. There was a slight increase in the levels ALT and AST activities in the treated group when compared with control. The treated group showed a significant increase in serum urea activity $(\mathrm{P}<0.05)$ when compared with the control. According to the results, Euphorbia hirta possessed erythropoiesis and hpyolipidemic activities [55]. The effects of the chromatographic fractions of Euphorbia hirta on the serum biochemical parameters were investigated in rats. The ethanolic extract was subjected to chromatographic separation, six fractions were obtained and were administered to rats in graded doses of $400 \mathrm{mg} / \mathrm{kg}, 800 \mathrm{mg} / \mathrm{kg}$ and $1600 \mathrm{mg} / \mathrm{kg}$ orally for fourteen days. Some fractions of this plant caused significant increase in the levels of total protein, albumin, globulin, alanine aminotransferase, alkaline phosphatase, aspartate aminotransferase, total bilirubin, creatinine, and blood urea nitrogen. Some fractions also caused significant decrease in the level of conjugated bilirubin [119]. The aqueous extracts of Euphorbia hirta $(400 \mathrm{mg} / \mathrm{kg}$ orally) in old mature male rats caused varying degrees of testicular degeneration and reduction in the seminiferous tubular diameter. Euphorbia hirta exerted potentially deleterious effects on the testes and accessory organs of rats [120]. The effects of Euphorbia hirta was studied on the ultrastructure of the liver, kidney and aorta in rat. Rats were fed with aqueous extracts of Euphorbia hirta at doses of 1,10 and $50 \mathrm{mg} / \mathrm{kg}$, respectively, every alternate day for 50 days, while one group served as a control. The animals were later sacrificed and the liver, kidney and aorta were harvested for examination by electron microscopy. The aorta showed no ultrastructural changes. Renal and hepatic tissue from the treated groups demonstrated dosedependent injuries, including architectural damage beginning in the nuclei and spreading outwards [121]. Among different whole plant extracts, the chloroform extract was found most irritant to rabbit's skin. Two fractions isolated from chloroform extract appeared to be the irritant components [56].

\section{Conclusion:}

The current paper reviewed the chemical constituent, pharmacological and therapeutic potential of Euphorbia hirta as promising herbal drug because of its safety and effectiveness.

\section{REFERENCES:}

[1] Al-Snafi AE. Medicinal plants possessed anti-inflammatory antipyretic and analgesic activities (part 2)plant based review. Sch Acad J Pharm 2016; 5(5): 142-158. http://saspublisher.com/wpcontent/uploads/2016/06/SAJP-55142-158.pdf

[2] Al-Snafi AE. Medicinal plants affected reproductive systems (part 2) - plant based review. Sch Acad J Pharm 2016; 5(5): 159-174. http://saspublisher.com/wp-content/uploads/2016/06/SAJP-55159-174.pdf

[3] Al-Snafi AE. Medicinal plants with anticancer effects (part 2)- plant based review. Sch Acad J Pharm 2016; 5(5): 175-193. http://saspublisher.com/wp-content/uploads/2016/06/SAJP-55175-193.pdf

[4] Al-Snafi AE. Antiparasitic, antiprotozoal, molluscicidal and insecticidal activity of medicinal plants (part 2) - plant based review. Sch Acad J Pharm 2016; 5(6): 194-207. http://saspublisher.com/wpcontent/uploads/2016/07/SAJP-56194-207.pdf

[5] Al-Snafi AE. Medicinal plants with antidiabetic effects (part 2): plant based review. IOSR Journal of Pharmacy 2016; 6(7): 49-61. http://www.iosrphr.org/papers/v6i7V2/F06724961.pdf

[6] Al-Snafi AE. Medicinal plants with antioxidant and free radical scavenging effects (part 2): plant based review. IOSR Journal Of Pharmacy 2016; 6(7): 62-82.

[7] Al-Snafi AE. Medicinal plants with antimicrobial activities (part 2): Plant based review. Sch Acad J Pharm 2016; 5(6): 208-239. http://saspublisher.com/wp-content/uploads/2016/07/SAJP-56208-239.pdf

[8] Al-Snafi AE. Medicinal plants with cardiovascular effects (part 2): plant based review. IOSR Journal of Pharmacy 2016; 6(7): 43-62. http://www.iosrphr.org/papers/v6i7V3/E067034362.pdf

[9] Al-Snafi AE. Detoxification capacity and protective effects of medicinal plants (part 2): plant based review. IOSR Journal of Pharmacy 2016; 6(7): 63-84.

[10] Al-Snafi AE. Beneficial medicinal plants in digestive system disorders (part 2): plant based review. IOSR Journal of Pharmacy 2016; 6(7): 85-92. http://www.iosrphr.org/papers/v6i7V3/G067038592.pdf

[11] Al-Snafi AE. Medicinal plants with central nervous effects (part 2): plant based review. IOSR Journal of Pharmacy 2016; 6(8): 52-75. http://www.iosrphr.org/papers/v6i8V1/G068015275.pdf

[12] Al-Snafi AE. Immunological effects of medicinal plants: A review (part 2). Immun Endoc \& Metab Agents in Med Chem 2016; 16(2): 100-121. http://www.eurekaselect.com/146338

[13] Al-Snafi AE. Medicinal plants affected male and female fertility (part 1)- A review. IOSR Journal of Pharmacy 2016; 6(10): 11-26. www.iosrphr.org/papers/v6i10V3/C0610031126.pdf

[14] Al-Snafi AE. Antiparasitic effects of medicinal plants (part 1)- A review. IOSR Journal of Pharmacy 2016; 6(10): 51-66. http://www.iosrphr.org/papers/v6i10V3/H0610035166.pdf

[15] Al-Snafi AE. Antimicrobial effects of medicinal plants (part 3): plant based review. IOSR Journal of Pharmacy 2016; 6(10): 67-92. http://www.iosrphr.org/papers/v6i10V3/I0610036792.pdf. 
[16] Al-Snafi AE. The pharmacological activities of Cuminum cyminum - A review. IOSR Journal of Pharmacy 2016; 6(6): 46-65. http://www.iosrphr.org/papers/v6i6V2/G066024665.pdf

[17] Al-Snafi AE. A review on Erodium cicutarium: A potential medicinal plant. Indo Am J P Sci 2017; 4(01): 110-116.

[18] Al-Snafi AE. Pharmacology of Echinochloa crus-galli - A review. Indo Am J P Sci 2017; 4(01): 117 122.

[19] Al-Snafi AE. The pharmacological potential of Dactyloctenium aegyptium- A review. Indo Am J P Sci 2017; 4(01): 153-159.

[20] Al-Snafi AE. Chemical constituents, pharmacological and therapeutic effects of Eupatorium cannabinum- A review. Indo Am J P Sci 2017; 4(01): 160-168.

[21] Al-Snafi AE. Nutritional and therapeutic importance of Daucus carota- A review. IOSR Journal of Pharmacy 2017; 7(2): 72-88.

[22] Al-Snafi AE. Chemical constituents and pharmacological effects of Dalbergia sissoo - A review. IOSR Journal of Pharmacy 2017; 7(2): 59-71.

[23] Al-Snafi AE. Medical importance of Datura fastuosa (syn: Datura metel) and Datura stramonium - A review. IOSR Journal of Pharmacy 2017; 7(2):43-58.

[24] Al-Snafi AE. A review on Dodonaea viscosa: A potential medicinal plant. IOSR Journal of Pharmacy 2017; 7(2): 10-21.

[25] Al-Snafi AE. The pharmacology and medical importance of Dolichos lablab (Lablab purpureus)- A review. IOSR Journal of Pharmacy 2017; 7(2): 22-30.

[26] Al-Snafi AE. Pharmacological and therapeutic importance of Desmostachya bipinnata- A review. Indo Am J P Sci 2017; 4(01): 60-66.

[27] Al-Snafi AE. Chemical constituents and pharmacological effects of Eryngium creticum- A review. Indo Am J P Sci 2017; 4(01): 67-73.

[28] Al-Snafi AE. The pharmacology of Equisetum arvense- A review. IOSR Journal of Pharmacy 2017; 7(2): 31-42.

[29] Al-Snafi AE. Medical importance of Cupressus sempervirens- A review. IOSR Journal of Pharmacy 2016; 6(6): 66-76. http://www.iosrphr.org/papers/v6i6V2/H066026676.pdf

[30] Al-Snafi AE. The contents and pharmacology of Crotalaria juncea- A review. IOSR Journal of Pharmacy 2016; 6(6): 77-86. http://www.iosrphr.org/papers/v6i6V2/I066027786.pdf

[31] Al-Snafi AE. Phytochemical constituents and medicinal properties of Digitalis lanata and Digitalis purpurea - A review. Indo Am J P Sci 2017; 4(02): 225-234.

[32] Al-Snafi AE. Therapeutic and biological activities of Daphne mucronata - A review. Indo Am J P Sci 2017; 4(02): 235-240.

[33] Al-Snafi AE. Pharmacological and therapeutic importance of Erigeron canadensis (Syn: Conyza canadensis). Indo Am J P Sci 2017; 4(02): 248-256.

[34] Al-Snafi AE. Eschscholzia californica: A phytochemical and pharmacological review. Indo Am J P Sci 2017; 4(02): 257-263.

[35] Al-Snafi AE. The contents and pharmacological importance of Corchorus capsularis- A review. IOSR Journal of Pharmacy 2016; 6(6): 58-63. http://www.iosrphr.org/papers/v6i6V3/F06635863.pdf

[36] Al-Snafi AE. The chemical constituents and pharmacological effects of Convolvulus arvensis and Convolvulus scammonia- A review. IOSR Journal of Pharmacy 2016; 6(6): 64-75. http://www.iosrphr.org/papers/v6i6V3/G06636475.pdf

[37] Al-Snafi AE. A review on chemical constituents and pharmacological activities of Coriandrum sativum. IOSR Journal of Pharmacy 2016; 6(7): 17-42. http://www.iosrphr.org/papers/v6i7V3/D067031742.pdf

[38] Al-Snafi AE. Pharmacology and toxicology of Conium maculatum- A review. The Pharmaceutical and Chemical Journal 2016; 3(2):136-142. http://tpcj.org/download/vol-3-iss-2-2016/TPCJ2016-03-02-136142.pdf

[39] Al-Snafi AE. The constituents and pharmacology of Cnicus benedictus- A review. The Pharmaceutical and Chemical Journal 2016; 3(2):129-135. http://tpcj.org/download/vol-3-iss-2-2016/TPCJ2016-03-02129-135.pdf

[40] Al-Snafi AE. Medicinal importance of Colchicum candidum- A review. The Pharmaceutical and Chemical Journal 2016; 3(2):111-117. http://tpcj.org/download/vol-3-iss-2-2016/TPCJ2016-03-02-111117.pdf

[41] Al-Snafi AE. Nutritional value and pharmacological importance of citrus species grown in Iraq. IOSR Journal of Pharmacy 2016; 6(8): 76-108. http://www.iosrphr.org/papers/v6i8V1/H0680176108.pdf 
[42] Al-Snafi AE. The pharmacological and toxicological effects of Coronilla varia and Coronilla scorpioides: A review. The Pharmaceutical and Chemical Journal 2016; 3(2): 105-114. http://tpcj.org/download/vol-3-iss-3-2016/TPCJ2016-03-03-105-114.pdf

[43] Al-Snafi AE. Pharmacological activities of Cotoneaster racemiflorus- A review. The Pharmaceutical and Chemical Journal 2016, 3(2):98-104. http://tpcj.org/download/vol-3-iss-3-2016/TPCJ2016-03-0398-104.pdf

[44] Al-Snafi AE. The constituents and pharmacology of Corchorus aestuans: A review. The Pharmaceutical and Chemical Journal 2016; 3(4):208-214. http://tpcj.org/download/vol-3-iss-4-2016/TPCJ2016-03-04208-214.pdf

[45] Al-Snafi AE. The chemical constituents and pharmacological activities of Cymbopagon schoenanthus: A review. Chemistry Research Journal 2016; 1(5):53-61. http://chemrj.org/download/vol-1-iss-52016/chemrj-2016-01-05-53-61.pdf

[46] Al-Snafi AE. Traditional uses, constituents and pharmacological effects of Cuscuta planiflora. The Pharmaceutical and Chemical Journal 2016; 3(4): 215-219. http://tpcj.org/download/vol-3-iss-42016/TPCJ2016-03-04-215-219.pdf

[47] Al-Snafi AE. A review on Dodonaea viscosa: A potential medicinal plant. IOSR Journal of Pharmacology 2017; 7(2): 10-21. http://www.iosrphr.org/papers/v7i2V1/B0702011021.pdf

[48] Al-Snafi AE. The pharmacology and medical importance of Dolichos lablab (Lablab purpureus)- A $\begin{array}{llllll}\text { review. IOSR JOurnal of Pharmacology 2017; } & \text { 7(2): }\end{array}$ http://www.iosrphr.org/papers/v7i2V1/C0702012230.pdf

[49] Al-Snafi AE. Pharmacological and therapeutic importance of Desmostachya bipinnata- A review. Indo Am J P Sci 2017; 4(01): 60-66.

[50] Al-Snafi AE. Chemical constituents and pharmacological effects of Eryngium creticum- A review. Indo Am J P Sci 2017; 4(01): 67-73.

[51] The plant list, a working list of all plant species, Euphorbia hirta, http://www.theplantlist.org/tpl/record/kew-80144

[52] Asha S, Deevika B and Mohamad Sadiq A. Euphorbia hirta Linn - A review on traditional uses, phytochemistry and pharmacology. World Journal of Pharmaceutical Research 2014; 3(4): 180-205.

[53] U.S. National Plant Germplasm System, Taxon: Euphorbia hirta L., https://npgsweb.arsgrin.gov/gringlobal/taxonomydetail.aspx?400051

[54] Pounikar Y, Jain P, Khurana N, Patil S, Omray LKand Gajbhiye A. Medicinal importance of Euphorbia hirta Linn. Sch Acad J Pharm 2013; 2(3):241-246.

[55] Akomas SC, Ijioma SN and Emelike CU. Effect of Euphorbia hirta on haematological and biochemical indices in albino rats. Applied Journal of Hygiene 2015; 4 (1): 1-5.

[56] Saeed-ul-Hassan S, Khalil-ur-Rehman M, Niaz U, Saeed MA, Hussain K, Rao SA and Ahmed I. Isolation and characterization of irritant components of Euphorbia pilulifera L. Pak J Pharm Sci 2013; .26(1):.31-37.

[57] Ping KY, Darah I, Chen Y, Sreeramanan S and Sasidharan S. Acute and subchronic toxicity study of Euphorbia hirta L. methanol extract in rats. Hindawi Publishing Corporation BioMed Research International 2013, http://dx.doi.org/10.1155/2013/182064

[58] Chopra N and Chopra IC. Chopra's indigenous drugs of India. $2^{\text {nd }}$ ed., UN Dhur \& Sons Private Ltd, India 1958: 507-508.

[59] Essiett UA and Okoko AI. Comparative nutritional and phytochemical screening of the leaves and stems of Acalypha fimbriata Schum. \& Thonn. and Euphorbia hirta Linn. Bull Env Pharmacol Life Sci 2013; 2 (4): $38-44$.

[60] Asha S, Thirunavukkarasu P and Mohamad Sadiq A. Phytochemical screening of Euphorbia hirta linn leaf extracts. World J Pharm Sci 2015; 3(6): 1104-1112.

[61] El-Mahmood MA. Antibacterial activity of crude extracts of Euphorbia hirta against some bacteria associated with enteric infections. Journal of Medicinal Plants Research 2009; 3(7): 498-505.

[62] Basma AA, Zakaria Z, Latha LY and Sasidharan S. Antioxidant activity and phytochemical screening of the methanol extracts of Euphorbia hirta L. Asian Pacific Journal of Tropical Medicine 2011; 4(5): 386-390.

[63] Rastogi RP, Mehrotra BN. 3rd. Lucknow, India: Central Drug Research Institute; Compendium of Indian Medicinal Plants, $3^{\text {rd }}$ Vol 2002.

[64] Kumar S, Malhotra R and Kumar D. Euphorbia hirta: Its chemistry, traditional and medicinal uses, and pharmacological activities. Pharmacogn Rev 2010; 4(7): 58-61.

[65] Chen L. Polyphenols from leaves of Euphorbia hirta L. Zhongguo Zhong Yao Za Zhi 1991;16(1):38-39. 
[66] Martínez-Vázquez M, Apan TOR, Lazcano ME and Bye R. Anti-inflammatory active compounds from the n-hexane extract of Euphorbia hirta. Revista de la Sociedad Química de México 1999; 43(3-4): 103-105.

[67] Aquil M and Khan IZ. Euphorbianin a new glycoside from Euphorbia hirta Linn. Global J Pure Applied Sci 1999; 5(3):38.

[68] Pioro-Jabrucka E, Pawelczak A, przybyl JL, Baczek K and Weglarz Z. Accumulation of phenolic and sterol compounds in Euphorbia hirta (L.). Herba Prolonica 2011; 1(57): 30-37.

[69] Igwe KK, Madubuike AJ, Akomas SC, Otuokere IE and Ukwueze CS. Studies of the medicinal plant Euphorbia hirta methanol leaf extract phytocomponents by GCMS analysis. International Journal of Scientific and Technical Research in Engineering 2016; 1(4): 9-16

[70] Shih MF and Cherng JY. Potential applications of Euphorbia hirta in pharmacology, drug discovery research in pharmacognosy. Omboon Vallisuta (Ed) 2012, http://www.intechopen.com/books/drugdiscovery-research-in- pharmac ognosy /potentialapplications- of-euphorbia-hirta-in-pharmacology

[71] Nguyen NT and Sosef MSM. Euphorbia L. In: dePadua LS, Bunyapraphastsara N and Lemmens RHMJ (editors). Plant resources of South East Asia, Medicinal and poisonous plants. Backhuys Publishers, Leiden, Netherlands 1999: 263-272.

[72] Enerva LT, Atienza TV, Glifonea ZR, Villamor OB and Villa NA. Cytotoxicity and antimicrobial property of the leaf extract of Euphorbia hirta (Tawa-Tawa). Open Journal of Social Sciences 2015; 3: 162-170.

[73] Pandey A and Verma N. Evaluation of antimicrobial activity of Euphorbia hirta and Calotropis procera against MDR patogenes. IJPAES 2013;3(3): 17-24.

[74] Rao B, Loganatan K, Elumalai EK and Kumar G. Antibacterial and antifungal activity of Euphorbia hirta 1. Leaves: A comparative study. Journal of Pharmacy Research 2010;. 3(3): 548.

[75] Jenifer S, Laveena DK, Priya S, Singh SJS and Jeyasree J. Antimicrobial screening of Euphorbia hirta L. and Pedalium murex L. A comparative study. World Journal of Pharmacy and Pharmaceutical Sciences 2014; 3(12): 1221-1226.

[76] Rajeh MA, Zuraini Z, Sasidharan S, Latha LY and Amutha S. Assessment of Euphorbia hirta L. leaf, flower, stem and root extracts for their antibacterial and antifungal activity and brine shrimp lethality. Molecules 2010; 15, 6008-6018.

[77] Upadhyay A, Chattopadhyay P, Goyary D, Mazumder PM and Veer V. Euphorbia hirta accelerates fibroblast proliferation and Smad-mediated collagen production in rat excision wound. Pharmacognosy Magazine 2014; 10(39): 534-542.

[78] Saravanan R, Dhachinamoorthi D, Senthilkumar K, Srilakshmi M and Sri TD. Antibacterial activity of Euphorbia hirta extracts. IJRAP 2012; 3(3): 439-441.

[79] Rajasekar TV, Anbarasu S, Manikkam R, Joseph J and Kumar V. Inhibitory activity of Euphorbia hirta (Tawa- tawa) extracts against Mycobacterium tuberculosis and other non mycobacterial pathogens. Der Pharma Chemica 2015; 7(8):213-216.

[80] Lacuna MLDG, Carmona ML, Amparado BB, Daclan MAF and Ranido LA. Antimicrobial activity of supercritical fluid extracts of two Philippine medicinal plants, Psidium guajava and Euphorbia hirta: Implications to community health. Advances in Agriculture \& Botanics - International Journal of the Bioflux Society 2013; 5(1): 1-12.

[81] Gayathri A and Ramesh KV. Antifungal activity of Euphorbia hirta L. inflorescence extract against Aspergillus flavus- A mode of action study. Int J Curr Microbiol App Sci 2013; 2(4):31-37.

[82] Varun K. Screening of Euphorbia hirta for antibacterial activity against plant patogenes. MSc thesis, Faculty of T- Anna University, Chennai 2014.

[83] Gyuris A, Szlávik L, Minárovits J, Vasas A, Molnár J and Hohmann J. Antiviral activities of extracts of Euphorbia hirta L. against HIV-1, HIV-2 and SIVmac251. In Vivo 2009; 23(3):429-432.

[84] Khurshid R, Saleem M, Karim S and Mir M. Antipyretic , antiviral and antithrombotic properties of Euphorbia hirta against Dengue fever. Pharmacia 2013;60(3): 8.

[85] Kandalkar A, Patel A, Darade S and Baviskar D. Free radical scavenging activity of Euphorbia hirta Linn. leaves and isolation of active flavonoid myricitrin. Asian Journal of Pharmaceutical and Clinical Research 2010; 3(3): 234-237.

[86] Lanhers MC, Fleurentin J, Cabalion P, Rolland A, Dorfman P, Misslin R, Pelt JM. Behavioral effects of Euphorbia hirta 1.: sedative and anxiolytic properties. Journal of Ethnopharmacology 1990; 29(2): 189-198.

[87] Landthers MC, Fleumntin J and Mortier F. Behavioral and neurotropic effects of an aqueous extract of Euphorbia hirta L. (Euphorbiaceae). Medicamews et Aliments: L Approche Ethnopharmacologique 1993: 298-302, Actes du Colloque Européen d'Ethnophmacologie et de la 1 le Conférence internationale d'Ethnomédecine, Heidelberg, 24-27 mars 1993. 
[88] Khan S, Ahmed B, Khalilullah H and Masoodi MH. Neuropharmacological activity of Euphorbia hirta and its isolated compound. Journal of Pharmacognosy and Phytochemistry 2014; 3 (2): 138-146.

[89] Singh GD, Kaiser P, Youssouf MS, Singh S, Khajuria A, Koul A, Bani S, Kapahi BK, Satti NK, Suri KA and Johri RK. Inhibition of early and late phase allergic reactions by Euphorbia hirta L. Phytotherapy Res 2006; 20(4): 316-321.

[90] Das P, Mekap S, Pani S, Sethi R and Nayak P. Pharmacological evaluation of anti-inflammatory activity of Euphorbia hirta against carrageenan induced paw edema in rats. Der Pharmacia Lettre 2010; 2(2): 151-154.

[91] Upadhyay A, Chattopadhyay P, Goyary D, Mazumder PM and Veer V. Anti-inflammatory effect of Euphorbia hirta leaf extract in rats and modulation of inflammation-associated prostaglandins (PGE-2) and nitric oxide (NO) expression in RAW264.7 macrophage. Journal of Pharmaceutical Sciences and Pharmacology 2014; 1: 68-73.

[92] Lanthers MC, Fleurentin J, Dorfman P, Mortier F and Pelt JM. Analgesic, antipyretic and antiinflammatory properties of Euphorbia hirta. Planta Med 1991; 57(3): 225-31.

[93] Shih MF, Cheng YD, Shen CR and Cherng JY. A molecular pharmacology study into the antiinflammatory actions of Euphorbia hirta L. on the LPS-induced RAW 264.7 cells through selective iNOS protein inhibition. J Nat Med 2010; 64(3): 330-335.

[94] Fayaz Ahmad S, Sultan P Ashour AE Khan TH Attia SM Bakheet SA and Abd-Allah AR. Modulation of Th1 cytokines and inflammatory mediators by Euphorbia hirta in animal model of adjuvant-induced arthritis. Inflammopharmacology 2013; 21(5): 365-375.

[95] Lee KH, Chen YS, Judson JP, Chakravarthi S, Sim YM and ER HM. The effect of water extract of Euphorbia hirta on cartilage degeneration in arthritic rats. Malays J Pathol 2008; 30(2):95-102.

[96] Romde RR, Ningwal M and Kaurav RK. Antihistaminic activity of Euphorbia hirta extract on asthmatic rats. IJAPBC 2014; 3(2): 434-436.

[97] Hellerman RC and Hazleton LW. The Antispasmodic Action of Euphorbia pilulifera. Journal of the American Pharmaceutical Association 1950; 39(3): 142-146.

[98] Uppal G, Nigam V and Kumar A. Antidiabetic activity of ethanolic extract of Euphorbia hirta Linn. Der Pharmacia Lettre 2012; 4(4):1155-1161.

[99] Kumar S, Rashmi and Kumar D. Evaluation of antidiabetic activity of Euphorbia hirta Linn. in streptozotocin induced diabetic mice. Indian J of Natural Products and Resources 2010; 1(2) 200-203.

[100] Widharna RM, Soemardji AA, Wirasutisna KR and Kardono LBS. Anti diabetes mellitus activity in vivo of ethanolic extract and ethyl aacetate fraction of Euphorbia hirta L. Herb. International Journal of Pharmacology 2010; 6(3): 231-240.

[101] Patill SB and Magdum CS. Determination of $\mathrm{LC}_{50}$ values of extracts of Euphorbia hirta Linn and Euphorbia neriifolia Linn using brine shrimp lethality assay. Asian J Res Pharm. Sci 2011; 1(2): 42-43.

[102] Liu Y, Murakami N, Jia H, Abreu P and Zhang S. Antimalarial flavonol Glycosides from Euphorbia hirta. Pharmaceutical Biology 2007; 45(4): 278-281.

[103] Rathnakumar K, Verma R, Jaikumar S and Sengottuvelu S. Antiulcer activity of Euphorbia hirta against experimentall induced ulcer in rats. International Journal of Pharmaceutical, Biological and Chemical Sciences 2013; 2(3): 16-20.

[104] Galvez J1, Zarzuelo A, Crespo ME, Lorente MD, Ocete MA and Jiménez J. Antidiarrhoeic activity of Euphorbia hirta extract and isolation of an active flavonoid constituent. Planta Med 1993; 59(4):333336.

[105] Tona L, Cimanga RK, Mesia K, Musuamba CT, Bruyne TD, Apers S, Hernans N, Miert SV, Pieters $\mathrm{L}$, Totte $\mathrm{J}$ and Vlietinck AJ. Antiamoebic and spasmolytic activities of extracts from some antidiarrhoeal traditional preparations used in Kinshasa, Congo. Phytomedicine 2000; 7(1): 31-38.

[106] Rathnakumar K, Ranbir V, Jaikumar S and Sengottuvelu S. Wound healing activity of ethanolic extract of Euphorbia hirta leaves on excision wound model in rats. Global J Res Med Plants \& Indigen Med 2013; 2(8): 571-575.

[107] Jaiprakash B, Chandramohan and Reddy DN. Burn wound healing activity of Euphorbia hirta. Ancient Science of Life 2006; 15(3\&4): 01-03.

[108] Johnson PB, Abdurahman EM, Tiam EA, Abdu-Aguye I and Hussaini IM. Euphorbia hirta leaf extracts increase urine output and electrolytes in rats. J Ethnopharmac 1999; 65(1): 63-69.

[109] Arollado EC, Peňaa IG and Dahiliga VRA. Platelet augmentation activity of selected Philippine plants. Int J Pharm Phytopharmacol Res 2013; 3 (2): 121-123.

[110] Jeje TO, Ibraheem O, Brai BC and Ibukun EO. Pharmacological potential of asthma weed (Euphorbia hirta) extract toward eradication of Plasmodium berghei in infected albino mice. Inter J of Toxicological and Pharmacological Research 2016; 8(3): 130-137. 
[111] Adedapo AA, Shabi OO, and Adedokun OA. Anthelmintic efficacy of the aqueous crude extract of Euphorbia hirta Linn in Nigerian dogs. Veterinarski Arhiv 2005; 75 (1): 39-47.

[112] Abdul Rahuman A, Gopalakrishnan G,Venkatesan P and Geetha K. Larvicidal activity of some Euphorbiaceae plant extracts against Aedes aegypti and Culex quinquefasciatus (Diptera: Culicidae), Parasitology Research 2007: 839-836.

[113] Singh SK, Yadav RP, TiwariS and Singh A. Toxic effect of stem bark and leaf of Euphorbia hirta plant against freshwater vector snail Lymnaea acuminata. Chemosphere 2005; 59(2): 263-270.

[114] Rames KV and Radmavati K. Assessment of Immunomodulatory Activity of Euphorbia hirta L. Indian Journal of Pharmaceutical Sciences 2010: 621-625.

[115] Pratheepa V and Sukumaran N. Effect of Euphorbia hirta plant leaf extract on immunostimulant response of Aeromonas hydrophila infected Cyprinus carpio PeerJ 2014; 2:e671; DOI 10.7717/peerj.671

[116] Tiwari P, Kumar K, Pandey AK, Pandey A, and Sahu PK. Antihepatotoxic activity of Euphorbia hirta and by using the combination of Euphorbia hirta and Boerhaavia diffusa extracts on some experimental models of liver injury in rats. International Journal of Innovative Pharmaceutical Research 2011; 2(2):126-130.

[117] Blanc P, de Sacqui-Sanners G and Lescure R. Galactogenic properties of plants of the African flora: Sersalisia djalionensis and E. hirta. Annales de Biologic Clinique 1964; 21 (10-12): 829-840.

[118] Williams LAD, Gossell-Williams M, Sajabi A, Barton EN and Fleischhacker R. Angiotensin converting enzyme inhibiting and anti-dipsogenic activities of Euphorbia hirta extracts. Phytother Res 1997; 11(5): 401-402.

[119] Adedapo AA, Abatan MO, Idowu SO and Olorunsogo OO. Effects of chromatographic fractions of Euphorbia hirta on the rat serum biochemistry. African Journal of Biomedical Research 2005; 8: 185189.

[120] Adedapo AA, Abatan MO, Akinloye AK, Idowu SO and Olorunsogo OO. Morphaometric and histopathological studies on the effects of some chromatographic fractions of Phyllanthus amarus and Euphorbia hirta on the male reproductive organs of rats. J Vet Sci 2003; 4(2):181-185.

[121] Wong JYR, Chen YS, CHakravarthi S, Judson JP, Santhana RL and Er HM. The effects of Euphorbia hirta on the ultrastructure of the murine liver, kidney and aorta. Exp Ther Med 2013; 6(5): 1247-1250. 